\title{
Lagrange and the Turin Academy of Sciences
}

\author{
Sandro Caparrini
}

Published online: 12 June 2014

(C) Centro P.RI.ST.EM, Università Commerciale Luigi Bocconi 2014

\begin{abstract}
A concise description of Lagrange's relationship to the Turin Academy of Sciences, from its foundation in 1757 to the end of the century.
\end{abstract}

Keywords Lagrange - Turin Academy of Science .

History of science - Eighteenth century science

At the beginning, the Turin Academy of Sciences was simply an occasion for three young lovers of science to meet [1]. It was 1757 and Turin was keeping pace with the scientific research of the times. In 1721 the university had been renovated; in 1748 the chair in experimental physics had been awarded to the illustrious cleric Giambattista Beccaria (1716-1781) and, that same year, a first Turinese scientific circle had been founded. The three friends had met at the university. Lagrange had recently been named assistant in the course of mathematics at Turin's Royal School of Artillery; Count Giuseppe Angelo Saluzzo di Monesiglio (1734-1810) was his colleague at that school and a lieutenant in the artillery corps; Giovanni Francesco Cigna (1734-1790) was studying medicine. All three attended Beccaria's courses.

The "Private Society" initially met at the house of Count Saluzzo:

Quivi si ritentavano con diligenza somma gli esperimenti degli uni, e si rileggevano i computi degli altri; quivi cimentavano essi l'un contro l'altro le loro forze librandosi così a più ardite pruove ed a voli più

S. Caparrini $(\bowtie)$

Dipartimento di Matematica, Università di Torino, Via Carlo

Alberto, 10, 10123 Turin, Italy

e-mail: sandro.caparrini@unito.it grandi; quivi la critica oculata, inseparabile dall'amore e dalla candidezza della fede, bandite le minuzie, e le lodi patteggiate, correggeva le opinioni coll'inchiesta del vero; quivi egregi e coraggiosi giovani erano per partorire eterna lode [2], p. 97.

(Here were attempted anew with extreme diligence the experiments of some, and reread the calculations of others; here they pitted their strengths against each other, so gliding to ever more daring trials and greater flights; here shrewd criticism, inseparable from the love and candour of faith, dispensed with minutiae, and negotiated praise, corrected opinions with true inquiry; here estimable and courageous young men were to give birth to eternal praise.)

The scientific conventicle grew rapidly. In 1759 appeared the first volume of the Miscellanea philosophicomathematica Societatis privatae Taurinensis. Important members were added from abroad: Haller, Euler, d'Alembert, Condorcet, Laplace and Monge. In 1760 these successes led Crown Prince Victor Amadeus to petition the king for permission for the Private Society to use the title "royal".

In 1766 Lagrange moved to Berlin, but he continued to follow the progress of the Society. On 23 November 1773 he wrote to Condorcet:

On m'a mande de Turin qu'on n'y parle plus du tout de l'établissement de la Société; peut-être à cause que le Roi des affaires plus importantes dans les tête ou peut-être aussi parce que, depuis la retraite du comte Saluce, on en aura abandonné le projet [3], vol. XIV, p. 16.

(I have received word from Turin that there is no talk at all of the institutionalisation of the Society; it may be because the King has more important matters in his mind, 
or it may also be that, after the retirement of Count Saluzzo, the project has been abandoned.)

As usual, Lagrange does not want to be bothered. In another letter to Condorcet of 4 September 1775, he adds, “Je n'intends plus parler de la Société de Turin, je crois que toutes les belles espérances qu'on avait s'en sont allées en fumé" (I hear no more talk about the Turin Society, I believe that all the fair hopes that we had have all gone up in smoke) [3], vol. XIV, p. 39.

In the meantime, the years went by. In 1770 Cigna was nominated full professor of anatomy and medical assistant in the S. Giovanni hospital. In 1775, Saluzzo, who Lagrange had named as executor of his affairs in Turin, was made the chief squire to the Princess Marie Clotilde of France, wife of Charles Emmanuel, Prince of Piedmont. Finally, on 25 July 1783, the "Royal Society" became the Royal Academy of Science, thanks to the new king, Victor Amadeus III of Sardinia. Today we are able to reconstruct the discussions that delayed the transformation, but basically these were due to petty intrigues of court. In 1784 the Academy was assigned as their headquarters the space that had been the theatre in the College of Nobles, a palace designed by Guarini and completed in 1687, which had become a property of the state following the suppression of the Jesuits in 1773.

Lagrange was told of the good news by both Saluzzo and Cigna. The mathematician and physicist Jakob II Bernoulli (1759-1789), who was passing through Berlin on his way to St. Petersburg, brought him a copy of new academy's statutes and royal patents. On 25 August 1783 Lagrange replied to his friends. These two letters, published only recently, reveal something more about the Turinese period of Lagrange's life.

The letter to Saluzzo [4], p. 127 is polite but formal: the friend of 20 years has become an "illustre Confrère" (illustrious colleague) to whom Lagrange (justly) attributes all credit for the success. It is in any case a remarkable success, since the transformation of the Private Society into a genuine academy had seemed blocked by insurmountable difficulties. Lagrange did not wish to be nominated honorary president; he was tempted to refuse, but feared being considered an ingrate. Thus he accepts, and begs the count to present his feelings of gratitude to the king and the ministers. He adds that the statute of the Academy seems perfect to him.

In contrast, the letter to Cigna [5] is forthright and amicable. Lagrange asks him about a few details: Has an official language been established for the proceedings? Will there be a section regarding the history of academy life? Will the number of academicians be fixed? Were the mathematicians Frisi and Fontana perhaps offended because they were preceded by Boscovich, Lorgna and Spallanzani in nominating the members of the academy?

Incidentally, from the correspondence we know Lagrange's opinions of some of the mathematicians mentioned in the letter. Boscovich is worth less than his works, which are in any case of little value [3], vol. XIV, 20. Frisi uses mathematical methods that are so erroneous that it is not worth arguing with him [3], vol. XIII, p. 291. Lorgna is openly ridiculed for having rediscovered theories that were 40 years old [3], vol. XIV, p. 255.

The final sentences of the letter to Cigna show an unusually expansive Lagrange: "Farewell, my dear friend. You have known for some time my feelings for you. I beg you never to doubt them, as I do not doubt yours towards me. I embrace you with all my heart". In effect, we have the impression that Cigna was one of the very few intimate friends of Lagrange.

Lagrange collaborated with the Miscellanea Taurinensia even after his move to Berlin. On 26 June 1785 he sent two more works to Count Saluzzo for the new Mémoires of the young academy. In the letter that accompanied them, he asks the count to give his regards to his Turinese friends and reiterates his declaration of affection:

Vous connaissez ceux que je vous ai voués depuis longtemp; ils n'ont fait qu'augmenter par les bontés que vous avez eues en dernier lieu par moi, et le nouveaux témoignages d'interet dont vous m'honorez dan votre lettre y ajoutant encore [4], p. 127.

(You know [the feelings] that I have long had for you; these have done nothing but increase because of the kindness that you have recently done me, and the new testimony of interest with which you honour me in your letter adds to them further.)

The two memoirs were published in vol. II of the Miscellanea Taurinensia. But they were the last.

(Translated from the Italian by Kim Williams)

\section{References}

1. Tra società e scienza: 200 anni di storia dell'Accademia delle Scienze di Torino. Allemandi, Torino (1988)

2. Il primo secolo della, R.: Accademia delle Scienze di Torino: notizie storiche e bibliografiche (1783-1883). Turin, Paravia (1883)

3. Lagrange, J.-L.: Euvres de Lagrange. Serret, Joseph Alfred. (ed.) vol. 14. Gauthier-Villars, Paris (1867-1892)

4. Giacardi, L., Roero, C.S. (eds.): Bibliotheca Mathematica: documenti per la storia della matematica nelle biblioteche torinesi. Allemandi, Turin (1987) 
5. Caparrini, S.: An Unpublished Letter by Lagrange Concerning the Turin Academy of Science. Atti della Accademia delle Scienze di Torino 141, Classe di Scienze Fisiche, Matematiche e Naturali, pp. 45-52 (2007)

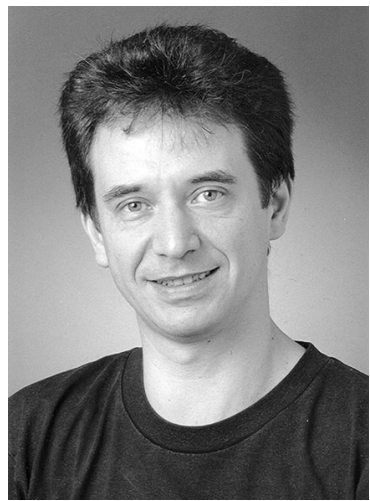

Sandro Caparrini holds degrees in Physics and in Mathematics and a Ph.D. in Mathematics from the University of Turin. His research interests are mainly focused on the history of the interaction between mathematics and mechanics from 1750 onward. He has held postdoctoral positions at the Dibner Institute (Harvard and MIT), at the Cohn Institute (Tel Aviv), at the Institute for the History and Philosophy of Science and

Technology (Toronto) and at the Dept. of Mathematics of the
University of Lille (France). In 2004 he was awarded the Slade Prize from the British Society for the History of Science. 